have been found at a depth of 90 metres. The author finds no evidence that the pelagic forms of Sargassum, which form the bulk of the floating algae in the Sargasso Sea, need to be constantly replenished from a benthonic source.

This section of the book concludes with a helpful chapter on the preservation and collection of specimens, a subject on which the author's painstaking work is well known.

The main text of some 600 pages is a descriptive catalogue of 750 species and 140 varieties, with keys for families, genera and species, bibliographical references, location and ecological notes. Uncertain records are listed at the end of the section on each genus. The book is illustrated by 74 beautifully executed line drawings and 20 black-and-white photographs.

The whole volume is the result of thirty years of patient and skilled endeavour by W. R. Taylor, his wife and a group of young workers. It has added greatly to algological knowledge, and at the same time it will be a foundation and indeed an inspiration, for further taxonomic and ecological work in an area for which no algal Flora had formerly been published. It is a pity that a map has not been included, particularly as locations are cited at the ends of descriptions of species.

LIIIY NEWTON

\section{STEROIDS AND CANCER}

\section{Biological Activities of Steroids in Relation to Cancer}

Proceedings of a Conference sponsored by the Cancer Chemotherapy National Service Center, National Cancer Institute, National Institutes of Health, U.S. Department of Health, Education and Welfare. Edited by Gregory Pincus and Erwin P. Vollmer. Pp. xvi +530. (New York: Academic Press, Inc.; London: Academic Press, Inc. (London), Ltd., 1960.) 15 dollars.

7 HIS book is the record of a conference of American endocrinologists, held in October 1959, to review the progress of a cancer therapy programme set up in 1955 by the U.S. National Cancer Institute. This record, complete with verbatim reports of the uninhibited discussions, reflects the high standard of present-day endocrinology in the United States, and the close alliance, if not identity, between clinical investigators and animal experimentalists. How ever, although the programme has clearly been intelligently organized and has already given grounds for cautious optimism, "Difficulty has been experienced in making use of information derived from animal studies. . . . The possibility exists that we may well become quite proficient at treating mouse and rat cancers, but not those found in man" ( $H$. Brendler). Even with animal tumours there are of course numerous difficulties; for example, the admixture of cells dependent on hormones and cells independent of hormones in rat mammary tumours induced by a technique which C. Huggins describes. His paper is notable for the international flavour of its list of references.

The papers on steroid chemistry (J. Fried), on the prostate as a target organ for steroids (W. W. Scott), and on steroid metabolism in human endocrine tumours (R. I. Dorfman) are informative in themselves and indicative of the range of subjects dealt with. V. A. Drill lucidly discusses the physiology and pharmacology of steroids in relation to the growth of experimental tumours. He also deals with the pituitary gland in a short section, which opens with the over-terse phrase: "Estrogens and androgens can inhibit the pituitary gland . . ."; in fact, only some of the functions of the pituitary are known to be thus inhibited. R. Vandewiele and S. Lieberman discuss the mysterious 'adrenal androgen' dehydroisoandrosterone-a major secretory product, the output being 15-25 mgm. a day in man. Among other papers on basic work, G. C. Mueller's is notable for shrewd experiments on possible points of action of oestrogens, ethanolamine phospholipids being a new candidate for consideration. Hydrogen transport may be another candidate in the view of P. Talalay and collaborators, but this view has been challenged.

While the book will be indispensable for clinical investigators, it also offers much of value to workers in basic disciplines, including chemistry. It contains not only an index but also a glossary. E. REID

\section{JUNGIAN PSYCHOLOGY}

The Structure and Dynamics of the Psyche By C. G. Jung. Translated by R. F. C. Hull. (The Collected Works of C. G. Jung, Vol. 8.) Pp. $x+596$. (London: Routledge and Kegan Paul, Ltd., 1960.) 42s. net.

7 THIS volume of Jung's collected works is not a book devoted to one developed theme but a collection of essays: 'some written many yoars ago and worked over more recently before publication. They are a witness to his incredible industry, which seems to have remained undiminished up to the very last years of his long life.

In a way it is a pity that he re-wrote such a great deal since one would like to have observed the evolution of his ideas. Some of the essays do show this, and the one "On Psychic Energy", for example, is really a defence of the stand he took after his book, Psychology and the Unconscious, caused such a violent opposition that he resigned his presidency of the International Psychoanalytical Society in 1913. In it he discusses symbol formation, myths and his views on the nature of the libido.

This book shows clearly both Jung's virtues and faults. There is no doubting his tremendous application, his great erudition, and originality. However, this is offiset by his vagueness and his tendency to interpret unknowns by unknowns. In spite of this, those interested in Jung's psychology should certainly read these essays. They will find considerable space devoted to his theories of complexes, archetypes and the structure of the psyche. The breadth of his reading is frightening, particularly when one considers that not only has he read very widely the literature of psychology from most countries but also he has made a deep study of mythology as woll.

The last essay will not be acceptable to many psychologists-it is on "Synchronicity: an Acausal Connecting Principle" and deals with extra-sensory perception.

Those interested in Jung's thought should certainly read this series. It is beautifully produced in a cloth binding with gold lettering, and clear print. The bibliography takes up seventeen pages and the index thirty-three. The translation by R. F. C. Hull is faultless.
C. Allen 